\title{
PENGARUH PENGGUNAAN MEDIA PENDIDIKAN TERHADAP PRESTASI BELAJAR PKN SISWA KELAS X SMK PERINDUSTRIAN YOGYAKARTA TAHUN PELAJARAN 2015/ 2016
}

\author{
Oleh: \\ Evi Yuliani Wandasari \\ NIM: 1040101482 \\ Universitas Cokroaminoto Yogyakarta
}

\begin{abstract}
Abstrak
Tujuan penelitian adalah ingin mengetahui adakah pengaruh penggunaan media pendidikan dalam meningkatkanpreswtasi belajar bidang studi PKn pada siswa kelas X SMK Perindustrian Yogyakarta.

Metode penelitian yang digunakan adalah deskriptif kuantitatif, dengan populasi berjumlah 120 siswa, sedangkan sampel dalam penelitian ini berjumlah 40 siswa. Metode pengumpulan data menggunakan angket, dan teknik analisis yang dipakai untuk menentukan kualifikasi manfaat dengan menggunakan prosesntase.

Hasil analisis data penelitian menunjukkan bahwa, pelaksanaan pembelajaran 75,594 \% (cukup), penggunaan media dalam pembelajaran hasilnya 77,517 \% (cukup), sedangkan sedangkan prestasi belajar adalah $82,895 \%$ (baik) dan manfaatnya dengan evaluasi adalah $74,898 \%$ masuk kategori cukup. Analisis korelasi menunjukkan adanya korelasi positif antara penggunaan media dengan prestasi belajar siswa, dengan harga kefisien korelasi rxy $=$ 0,4717. Jadi dapat disimpulkan bahwa penggunaan media pendidikan dapat meningkatkan prestasii belajar bidang studi PKn pada siswa kelas X SMK Perindustrian Yogyakarta.
\end{abstract}

Kata kunci: Penggunaan Media dan Prestasi Belajar

\section{PENDAHULUAN}

Di dalam semua organisasi sosial, ekonomi, politik dan budaya hampir semua menyadari akan pentingnya penggunaan media komunikasi yang tepat. Media komunikasi bukan dianggap lagi sebagai suatu barang mewah, melainkan sering dianggap bahwa tanpa media yang lengkap, tepat dan serasi, maka akan dirasakan sulit untuk tercapainya program organisasi.

Kesadaran ini juga menjalar dalam dunia pendidikan baik pendidikan formal di sekolah maupun dalam pendidikan non formal di luar sekolah. Media komunikasi yang digunakan dalam dunia pendidikan umumnya disebut "Media Pendidikan".

Mengingat sangat pentingnya peranan pendidikan bagi kehidupan, maka pendidikan harus dilaksanakan sebaik-baiknya sehingga memperoleh hasil sesuai yang diharapkan. Dalam Undang-Undang Nomor 20 tahun 2003 tentang Sistem Pendidikan Nasional, dalam pasal 3 disebutkan:

"Pendidikan nasional berfungsi mengembangkan kemampuan dan membentuk watak serta peradaban bangsa yang bermartabat dalam rangka mencerdaskan kehidupan 
bangsa, bertujuan untuk berkembangnya potensi didik agar menjadi manusia yang beriman dan bertakwa kepada Tuhan Yang Maha Esa berakhlak mulia, sehat, berilmu, cakap, kreatif, mandiri dan menjadi warga negara yang demokratis serta bertanggung jawab (UU No.2 tahun $2003 ; 8$ )".

Dalam tujuan Pendidikan Nasional tersebut adanya usaha peningkatan kualitas sumber daya manusia Indonesia seutuhnya dengan melalui suatu sistem pendidikan sebagai sarana dalam upaya pembentukan ilmu pengetahuan cakap, kreatif dan mandiri, demokratis serta bertanggungjawab merupakan sarana terpenting dalam membangun bangsa itu. Sehingga pendidikan itu sebagai media merupakan alat dalam upaya mencerdaskan bangsa itu.

Dewasa ini semua organisasi sosial, ekonomi, politik dan budaya hampir semuanya menyadari akan pentingnya penggunaan media komunikasi yang tepat. Media komunikasi dewasa ini sangat diutamakan dalam meningkatkan tingkat pembelajaran. Media pendidikan sebagai sarana mempermudah transfer pengetahuan sangat penting lebih-lebih pada anak. Media pendidikan yang semakin diharapkan dapat memberikan kemudahan dalam mentransfer ilmu pengelahuan. Media pendidikan merupakan alat mentransfer pengetahuan. Usaha-usaha ke arah peningkatan kualitas pendidikan dapat terlihat dari adanya upaya-upaya untuk memperbaharui dan mengembangkan kurikulum, meningkatkan profesional atas kemampuan tenaga pendidik, penyempurnaan prasarana pendidikan seperti laboratorium, perpustakaan dan lain-lain, baik dan untuk jenjang pendidikan dasar, pendidikan menengah maupun pendidikan tinggi. Sebagai negara yang sedang giat membangun, pemerintah Indonesia kini tengah berupaya meningkatkan sumber daya manusia yang berkualitas. Upaya ini dilakukan dengan pelaksanaan pendidikan yang bernuansa inovatif dan kreatif. Terutama yang berkenaan dengan meningkatkan mutu pada para lulusan sekolah yang diharapkan dapat sesuai dan memenuhi kebutuhan pembangunan, sehingga prioritas pembangunan di bidang pendidikan ini sangat diperhatikan oleh pemerintah.

Pendidikan ini sendiri menurut Rachmat Jatun adalah sebagai berikut:

"Ditinjau dari sudut sosiologi maka pendidikan itu berfungsi membimbing anak agar lebih dapat hidup serasi dengan masyarakat dengan cara membekali kemampuan pada anak, ditinjau dari sudut psikologi pendidikan adalah perkembangan manusia terdiri dari perkembangan jasmaniah, ditinjau dari sudut filosofis pendidikan itu merupakan integrasi potensi-potensinya sebagai makhluk pribadi, sosial dan makhluk susila" (1989 : 141).

Pendidikan itu sebagai sarana pembentuk ilmu pengetahuan suatu kelompok atau suku bangsa, merupakan sarana terpenting dalam membangun bangsa itu, sehingga pendidikan itu sebagai media merupakan bentuk alat dalam upaya mencerdaskan bangsa itu. Dewasa ini 
semua organisasi sosial, ekonomi, politik dan budaya hampir semuanya menyadari akan pentingnya penggunaan media komunikasi yang tepat.

Di dalam pendidikan kita mengenai berbagai istilah peragaan. Ada yang lebih senang menggunakan istilah peragaan, tetapi ada pula yang menggunakan istilah komunikasi keperagaan. Dewasa ini telah mulai dipopulerkan istilah baru yakni "Media Pendidikan". Sedangkan untuk pengertian yang sama, banyak pula ahli vang menggunakan istiiah "teaching material atau instructional material".

Media pendidikan sebagai sarana mempermudah proses mentransfer pengetahuan, pada era modernisasi millenium ini berbagai alat dan media bermunculan semakin praktis, kreasi dan semakin maju. Mungkin pada saatnya manusia baru mengenai pendidikan, media pendidikan yang digunakan masih sangat sederhana, mungkin hanya diingat-ingat saja dalam angan-angan atau ditorehkan pada sebuah batu, kayu, atau benda-benda lain yang dimungkinkan dapat bertahan dan masa ke masa. Namun sekarang ini media pendidikan yang semakin maju diharapkan dapat memberikan kemudahan yang lebih pada ilmu pengetahuan yang akan diungkap.

Demikian pula dengan kemudahan-kemudahan media pendidikan pada jaman modern ini diharapkan dapat memacu prestasi belajar. Dengan minat belajar yang semakin tinggi ini diharapkan kemudian akan diperoleh prestasi belajar yang meningkat pula. Demikian pula dalam PKn, sangat diperlukan media pendidikan, sehingga materi yang sifatnya abstrak dalam PKn menjadi lebih jelas.

\section{KAJIAN TEORI}

A. Media Pendidikan

1. Pengetian Media Pendidikan

Di dalam semua organisasi sosial, ekonomi, politik dan budaya hampir semuanya menyadari akan pentingnya penggunaan media komunikasi yang tepat. Media komunikasi bukan lagi dianggap sebagai suatu barang mewah, melainkan merupakan syarat mutlak bagi keberhasilan program kerja organisasi itu. Bahkan sering dianggap bahwa tanpa media yang lengkap, tepat dan serasi, maka akan dirasakan sulit untuk tercapainya program organisasi.

Kesadaran ini juga menjalar dalam dunia pendidikan, baik pendidikan formal di sekolah maupun dalam pendidikan non formal di luar sekolah. Media komunikasi yang digunakan daiam dunia pendidikan umumnya disebut "Media Pendidikan".

Oemar Hamalik dalam bukunya Media Pendidikan mengartikan bahwa: 
Media pendidikan adalah alat, metode dan teknik yang digunakan dalam rangka lebih mengefektifkan komunikasi dan interaksi antara guru dan siswa dalam proses pendidikan dan pengajaran di sekolah. (1996: 23).

Di dalam pendidikan kita mengenal berbagai istilah peragaan. Ada yang lebih senang menggunakan istilah peragaan, tetapi ada pula yang menggunakan istilah komunikasi keperagaan. Dewasa ini telah mulai dipopulerkan istilah, baru yakni "Media Pendidikan". Sedangkan dalam pengertian yang sama, banyak pula ahli yang menggunakan istilah "teaching material atau instructional material".

Ciri-ciri umum dari media pendidikan adalah sebagai berikut:

a. Media pendidikan identik artinya dengan pengertian keperagaan, yang berasal dari kata "raga" artinya suatu benda yang dapat diraba, didengar dan dapat diamati melalui pancaindera.

b. Tekanan utama terletak pada benda atau hal-hal yang bias dilihat dan didengar.

c. Media pendidikan digunakan dalam rangka hubungan (komunikasi) dalam pengajaran, antara guru dan siswa.

d. Media pendidikan adalah semacam alat Bantu belajar mengajar, baik dalam kelas maupun di luar kelas.

e. Berdasarkan b dan d, maka pada dasarnya media pendidikan merupakan suatu "perantara" (medium, media) dan digunakam dalam rangka pendidikan.

f. Media pendidikan menganduk aspek-aspek: sebagai alat dan sebagai teknik yang sangat erat pertaliannya dengan metode mengajar.

g. Karena itu sebagai tindakan operasional, maka dalam hal ini digunakan pengertian "Media Pendidikan". (R. Warsito, 1999: 34)

Jadi yang dimaksud dengan media pendidikan adalah alat, metode dan teknik yang digunakan dalam rangka lebih mengefektifkan komunikasi dan interaksi antara guru dengan siswa dalam proses pendidikan dan pengajaran.

2. Nilai atau Manfaat Media Pendidikan

Nilai atau manfaat media pendidikan adalah sebagai berikut:

a. Meletakkan dasar-dasar yang konkrit untuk berfikir oleh karena itu mengurangi "verbalisme".

b. Memperbesar perhatian para siswa.

c. Meletakkan dasar-dasar yang penting untuk perkembangan belajar, dan oleh karena itu membuat pelajaran lebih mantap. 
d. Membenkan pengalaman yang nyata yang dapat menumbuhkan kegiatan berusaha sendiri di kalangan siswa.

e. Menumbuhkan pemikiran yang teratur dan kontinyu, ini terutama dalam gambar hidup.

f. Membantu tumbuhnya pengertian, dengan demikian membantu perkembangan kemampuan berbahasa.

g. Memberikan pengalaman-pengalaman yang tidak mudah diperoleh dengan cara lain serta membantu berkembangnya efisiensi yang lebih mendalam serta keragaman yang lebih banyak dalam belajar. (Oemar Hamalik, 1996:27)

Selain itu dalam buku Media Pendidiknn dikemukakan bahwa terdapat sejumlah nilai praktis dari media pendidikan yaitu sebagai berikut:

a. Media pendidikan melampaui batas pengalaman pribadi siswa.

b. Media pendidikan melampaui batas-batas ruangan kelas.

c. Media pendidikan memungkinkan terjadinya interaksi langsung antara siswa dan lingkunganya.

d. Media pendidikan memberikan uniformitas/kesamaan dalam pengamatan. Siswa yang hanya pernah melihat ikan asin akan berbeda persepsinya dengan siswa yang telah melihat dan memakan ikan asin. Persepsi yang sama akan menimbulkan pengertian dan pengalaman yang sama.

e. Media pendidikan akan memberikan pengertian atau konsep yang sebenarnya secara realitas dan teliti. Dengan menggunakan media pendidikan seperti gambar, model, film dan lain-lain, para siswa dapat diberi konsep yang besar, tepat dan lengkap tentang sesuatu yang sedang dipelajari.

f. Bunyi suara yang terlalu halus yang tidak mungkin didengar. Dengan media pendidikan dapat didengar.

g. Hal-hal lain seperti iklim, terbentuknya sebuah ngarai, tiupan angin, pergantian musim, dan lain-lain dapat dilihat proses terjadinya dengan menggunakan media pendidikan. (Oemar Hamalik, 1996:28)

Dari uraian tersebut jelaslah bahwa, media pendidikan menpunyai peran yang sangat besar, terhadap pendidikan para siswa. Karena media membantu siswa dalam memahami konsep tertentu yang tidak dapat dijelaskan dengan bahasa.

3. Tujuan Pendidikan dan Media Pendidikan

Tujuan pendidikan akan mengarahkan semua proses pendidikan. Berdasarkan tujuan pendidikan itu semua perencanaan pengajaran, kegiatan pendidikan dapat diarahkan kepada pembentukan manusia yang diharapkan oleh masyarakat. 
Secara praktis proses pencapaian tujuan itu melalui suatu proses pengajaran yang direncanakan oleh sekolah, atau dengan kata lain, sekolah menyediakan suatu lingkungan pendidikan yang serasi dengan usaha pencapaian tujuan pendidikan.

Ditinjau dari struktural, Oemar Hamalik (1996:40) mengemukakan bahwa tujuan pendidikan dapat dibagi tingkatannya sebagai berikut:

a. Tujuan Pendidikan Nasional

b. Tujuan Institusional

c. Tujuan kurikuler

d. Tujuan intruksional umum (TIU) tujuan umum pembelajaran (TUP)

e. Tujuan intruksional khusus (TIK), tujuan khusus pembelajaran (TKP).

Ditinjau dan segi horisontal, tujuan dibagi menjadi :

a. Tujuan Umum

Yaitu tujuan yang diinginkan oleh masyarakat umum sesuai dengan kebutuhan dan citacita masyarakat itu.

b. Tujuan Khusus

Adalah tujuan yang merupakan penjabaran secara rinci dari pada tujuan umum.

c. Tujuan Guru

Adalah tujuan yang diharapkan oleh guru, yakni perubahan dalam berbagai aspek tingkah laku siswa.

d. Tujuan Siswa

Adalah tujuan yang berdasarkan pada keinginan dan minat siswa.

Media pendidikan sebagai suatu media komunikasi guru dan siswa dalam pengajaran, sudah tentu sangat erat pertaliannya dengan proses belajar mengajar. Oleh karena itu jelas bahwa media belajar mengajar sangat penting bagi media pendidikan, ada 5 hal tujuan pendidikan:

a. Tujuan pengajaran menentukan arah yang hendak dicapai oleh media pendidikan.

b. Tujuan pengajaran menentukan alat/media pendidikan apa yang hendak digunakan.

c. Tujuan pengajaran menentukan metode pendidikan apa yang akan digunakan oleh guru dalam membimbing kegiatan belajar siswa.

d. Tujuan pengajaran menentukan proses kegiatan komunikasi pendidikan sekolah.

e. Tujuan pengajaran menentukan teknik penilaian terhadap penggunaan media pendidikan.

f. Tujuan pengajaran menentukan arah dan kebijaksanaan yang ditempuh dalam admmistrasi media pendidikan di sekolah. (1996: 29) 


\section{Guru dan Media Pendidikan}

Pekerjaan guru adalah pekerjaan profesional. Karena itu diperlukan kemampuan dan kewenangan. Kemampuan itu dapat dilihat dari kesanggupannya menjalankan peranannya sebagai guru, pengajar pembimbing, administrator, dan sebagai pembina ilmu. Salah satu dari kemampuan itu ialah sejauh manakah ia menguasai metodologi media pendidikan di sekolah untuk kepentingan anak didiknya, sehingga memungkinkan perkembangan mereka secara optimal sesuai dengan tujuan pendidikan.

Dalam bidang ini, setiap guru akan berhadapan dengan setidak-tidaknya lima tantangan yakni:

a. Apakah ia memiliki pengetahuan, pemahaman dan pengertian yang cukup tentang media pendidikan?

b. Apakah ia memiliki ketrampilan tentang cara menggunakan media tersebut dalam proses belajar mengajar di kelas ?

c. Apakah ia mampu membuat alat-alat sendidri yang dibutuhkan ?

d. Apakah ia mampu melakukan penilaian terhadap media yang akan atau yang telah digunakan?

e. Apakah ia memiliki pengetahuan dan ketrampilan dalam bidang administrasi media pendidikan?

Sedap guru harus memiliki pengetahuan dan pemahaman yang cukup tentang media pendidikan. Pengetahuan itu meliputi:

a. Media sebagai alat komunikasi guna lebih mengefektifkan PBM.

b. Fungsi media dalam rangka mencapai tujuan pendidikan.

c. Hubungan antara mengajaran dengan media pendidikan.

d. Nilai atau manfaat media pendidikan

e. Memilih dan menggunakan media pendidikan

f. Tentang proses-proses belajar mengajar

g. Memilih dan menggunakan media pendidikan

h. Berbagai jenis alat dan teknik media pendidikan

i. Usaha inovasi dalam media pendidikan dan lainnya, dalam (Oemar Hamalik, 1996: 32).

Dititik dan beberapa pokok ang telah dikemukakan di atas, jelaslah bahwa media pendidikan merupakan alat dan sarana pengajaran yang diperlukan bersifat melengkapi sebagai upaya guru memberikan materi pengajaran kepada siswa dengan metode yang paling efektif dan praktis. 
Memilih dan menggunakan media pendidikan harus sesuai dengan kriteria dengan kriteria-kriteria yaitu:

a. Tujuan Mengajar

b. Bahan pelajaran

c. Metode mengajar

d. Tersedianya alat yang dibutuhkan

e. Jalan pelajaran

f. Penilaian hasil belajar

g. Pribadi guru

h. Minat dan kemampuan siswa

i. Situasi pengajaran yang sedang berlangsung, menurut (Oemar Hamalik, 1996: 32).

Ketrampilan membuat media pendidikan berarti terampil dan menguasai tehnik serta proses pembuatan suatu media pendidikan yang berguna untuk suatu pelajaran tertentu. Alatalat yang digunakan harus memenuhi syarat-syarat sebagai berikut:

a. Rasional sesuai dengan akal dan mampu dipikirkan oleh manusia.

b. Ilmiah, sesuai dengan perkembangan ilmu pengetahuan

c. Ekonomis, sesuai dengan kemampuan pembiayaan yang ada

d. Praktis dapat digunakan dalam kondisi praktek di sekolah dan bersifat sederhana, menurut (Oemar Hamalik, 1996: 32).

\section{Penilaian Media Pendidikan}

Menilai sesuatu media pendidikan merupakan suatu pekerjaan yang cukup rumit. Guru harus pandai menerapkan kriteria-kriteria penilaian untuk melihat apakah sesuatu alat memenuhi persyaratan atau tidak.

Penilaian itu dilaksanakan dalam rangka:

a. Memilih jenis alat yang akan dipakai

b. Atau sesudah menggunakan alat

c. Atau pada waktu orang lain sedang menggunakan sesuatu alat dalam kelas.

Pekerjaan administrasi dapat ditafsirkan dalam arti yang sempit atau dalam arti yang luas. Dalam arti yang sempit hanya meliputi pekerjaan ketatausahaan biasa, seperti, mendaftar, mengatur, menyimpan dan lain-lain. Dalam arti yang luas, administrasi adalah meliputi perencanaan, penyusunan, pelaksanaan, pengawasan dan penelitian. 


\section{Pola Media Pendidikan}

Secara menyeluruh pola media pendidikan terdiri dari:

a. Bahan-bahan cetakan atau bacaan

Bahan-bahan bacaan itu seperti: buku, komik koran, majalah, periodikal (berkala) pamflet dan lain-lain.

Bahan-bahan ini lebih mengutamakan kegiatan membaca atau penggunaan simbolsimbol kata dan visual.

b. Alat-alat audio visual

Alat-alat yang tergolong ke dalam kategori ini, terdiri dari :

1) Media pendidikan tanpa proyeksi

Seperti: papan tulis, papan tempel bagan, grafik; poster, kartoon, komik, gambar.

2) Media pendidikan tiga dimensi

Seperti: model, benda asli, benda druan diorama, boneka, topeng, peta timbul, globe, museum.

3) Media pendidikan yang menggunakan teknik atau manual.

Seperti: slide, film, rekaman, radio, televisi, komputer dan lain-lain.

c. Sumber-sumber masyarakat

Berupa objek-objek peninggalan sejarah, dokumentasi, bahan-bahan, masalah-masalah dari berbagai bidang yakni meliputi: daerah, penduduk, sejarah, jenis-jenis kehidupan, mata pencaharian, industri, perbankan, perdagangan, pemerintahan, kebudayaan, politik dan lain-lain.

d. Material collections (kumpulan benda-benda) Berupa benda-benda atau barang-barang yang dibawa dan masyarakat ke sekolah untuk dipelajari, seperti: potongan kaca, potongan sendok, daun, benih, bahan kimia, daerah dan lain-lain.

e. Contoh kelakuan yang ditampilkan atau diperagakan oleh guru.

Meliputi semua contoh kelakuan yang ditunjukan oleh guru sewaktu mengajar, misalnya, gerakan tangan, gerakan kaki, gerakan badan, mimik dan lain-lain. Keperagaan yang tergolong dalam kategori ini tidak sangat banyak macamnya dan sangat bergantung kepada kreasi dan inisiatif pribadi guru sendiri. Tetapi pada pokoknya jenis media ini hanya dapat dilihat didengar, dan ditiru oleh siswa, menurut (Ocmar Hamalik, 1996:32). 
7. Alat-alat bantu pengajaran

Alat bantu mengajar atau media mengajar merupakan bagian dari teknologi pengajaran, pada umumnya berupa alat-alat atau sarana yang dapat dipergunakan lewat indera mata dan telinga. Karena itu alat-alat tersebut disebut "alat-alat dengar pandang". (AVA : Audio-VisualAids).

Kemajuan teknik cetak mencetak dan teknologi elektronika sangat mengembangkan alat bantu mengajar masa kini terdiri dari:

a. Alat bantu dasar: sabak papan tulis , gambar, peta chart, atlas, globe, model, kertas, pena, cat, dan sebagainya.

b. Alat bantu cetak: buku teks, majalah, famplet, berkala, referens.

c. Alat bantu pandang: artefak, benda seni, papan buletin, grafika, film strip, slide, model transparan.

d. Alat bantu dengar: audio tape, radio, telephone.

e. Alat bantu dengar pandang: gambar hidup, televisi video tape.

f. Alat bantu lain-lain: bahan observasi, museum, tempat-tempat bersejarah (Oemar Hamalik, 1996 : 34).

Untuk mengaktifkan murid di dalam proses belajar mengajar sangat dibutuhkan adanya media/ alat bantu yang sesuai dengan bahan yang diajarkan. Penerapan kurikulum baru di sekolah-sekolah sekarang ini juga menggariskan tentang perlunya mengaktifkan murid dalam proses belajar mengajar dengan berbagai kegiatan. Kegiatan-kegiatan ini tentu dapat terlaksana dengan adanya media/alat bantu. Jadi jelaslah bagi kita bahwa penggunaan media pendidikan juga harus didasarkan pada kurikulum.

Adapun fungsi dari media pendidikan adalah sebagai berikut:

a. Dapat membantu kemudahan belajar dari siswa dan kemudian mengajar bagi guru.

b. Melalui alat bantu pengajaran konsep/tema pelajaran yang abstrak dapat diwujudkan dalam bentuk konkrit.

c. Menarik perhatian yang lebih besar kepada siswa sehingga siswa tidak merasa bosan.

d. Dapat mengaktifkan dan membuat semua indra siwa bekerja.

e. Lebih menarik minat, kesenangan murid serta memberikan fariasi atau mendekati style (cara kesenangan) belajar murid-murid.

f. Membantu mendekatkan dunia teori/ konsep dengan realitasnya. 
Lebih jauh disini akan dikemukakan beberapa prinsip umum yang sebaiknya dihayati oleh setiap guru didalam penggunaan media. Adapun prisinp-prinsip umum yang dapat dikemukakan adalah:

a. Penggunaan media pengajaran hendaknya dipandang sebagai bagian yang manunggal (integrated) dengan proses atau sistem mengajar/bukan merupakan tambahan ekstra yang digunakan apabila waktu mengizinkan atau kalau senggang waktu saja.

b. Media pengajaran hendaknya dipandang sebagai sumber daripada data. Dalam teknik inkuiri, pemecahan masalah atau diskusi sering hal itu dibutuhkan.

c. Bahwa dalam penggunaan media pengajaran guru hendaknya memahami benar tingkat hierarki (sequensi) daripada jenis dan kegunaannya. Sebab sebagaimana kita pahami, siswa lebih mudah menghayati yang konkrit dari pada yang abstrak.

d. Bahwa penggunaan media pengajaran seyogyanya diuji kebenarannya sebelum, selama, dan sesudah penggunaannya.

e. Media pengajaran akan sangat efektif dan efisien penggunaannya apabila diorganisir secara sistematis.

f. Penggunaan multi media pengajaran akan sangat menguntungkan dan memperlancar proses belajar mengajar siswa serta merangsang gairah siswa (Oemar Hamalik. 1996: $35)$.

\section{Pemilihan Media}

Kriteria Pcnentuan Pemilihan Media menurut John Jarolimek yang dikurip Oemar Hamalik mengutarakan 5 hal yang hendaknya diperhatikan dalam menentukan pilihan media yaitu:

a. Tujuan instruksional yang ingin dicapai

b. Tingkat usia dan kematangan anak

c. Kemampuan baca dari anak

d. Tingkat kesulitan dan jenis konsep pelajaran tersebut

e. Keadaan latar belakang pengetahuan dan pengalaman anak John Michael menambahkan.

f. Jenis ragam dari media tersebut jangan sampai membingungkan. Selain di atas, ditambahkan pula oleh Kosasi Djahiri.

g. Keadaan dan kemampuan ekonomi guru, sekolah, siswa dan masyarakat.

h. Keadaan dan kemampuan guru dalam menggunakan hal tersebut.

i. Tingkat kegunaan atau manfaatnya. 
Tingkat Heararki Media:

a. Pengalaman kehidupan langsung

b. Pernyataan yang bersangkutan dalam suatu pengalaman buatan (simulasi, artifical; yang dibuat-buat/buatan).

c. Observasi dan parrisipasi langsung dalam objek studi antara lain karyawisata.

d. Observasi dan partisipasi tidak langsung antara lain: TV, Slide, Film lengkap.

e. Hampir sama di atas ialah memprestasikan/mempertontonkan/ memvisualisasikan objek dengan slow motion picture, foto-foto, hanya di atas lebih hidup dan keseluruhannya langsung.

f. Melalui alat media (pendengaran): radio, tape recorder

g. Bahan bacaan

h. Kemampuan rnendengarkan

i. (Catatan: kronologis di atas berjalan dari konkrit menuju bentuk-bentuk abstrak) (Oemar Hamalik, 1996: 39).

9. Jenis-jenis media pengajaran

Ada beberapa pendapat yang dikelompokan ke dalam jenis-jenis (ragam) dari media pengajar. Menurut A. Kosasih Djahin jenis (ragam) media pengajaran adalah sebagai berikut:

a. Bahan bacaan, seperti: buku, koran, majalah, dan bahan corak lainnya.

b. Bahan kemasyarakatan antara lain: manusia sumber guest lecturer (guru tamu), studi lapangan, observasi, survey lapangan dan lain-lain.

c. Bahan AVA (Audio Visual Aids) antara lain: model, bagan, gambar film dalam segala jenis, radio, TV, grafik, globe, dan lain-lain.

d. Kegiatan-kegiatan yang dilakukan siswa secara individual, kelompok, atau bersama guru, antara lain: Simulasi, game, role playing, penulisan dan lain-lain.

Menurut pendapat yang lain, media pengajaran terdiri atas

beberapa jenis (ragam) yaitu:

a. Media grafik terdiri atas:

1) Gambar/ foto (media yang paling umum dipakai dan mudah didapat.

2) Skesta, adalah gambar yang sederhana/daftar kasar yang melukiskan bagian-bagian pokoknya tanpa detail.

3) Diagram, suatu gambar menggunakan garis-garis dan simbol-simbol geometris yang konvensional. 
4) Grafik, adalah suatu jenis grafis yang menggambarkan titik-titik atau garis untuk menyampaikan informasi statistik yang saling berhubungan.

5) Karton, adalah suatu gambar interpretasi yang menggunakan simbolisme dan seringkali melebih-lebihkan secara berani.

6) Poster, penting peranannya dalam proses belajar mengajar karena dapat membantu mengubah tingkah laku anak.

7) Peta atau Globe, sebagai menyajian visual atas bumi atau permukaan bumi, peta dan globe mempunyai beberapa kelebihan jika dipakai sebagai media kegiatan belajar mengajar di sekolah.

b. Media Audio, terdiri atas:

1) Radio

Sebagai suatu media, radio mempunyai beberapa kelebihan jika dibanding jika dibanding dengan media lain, yaitu:

a) Harganya lebih murah, variasi programnya lebih banyak daripada TV.

b) Sifatnya-mobile, radio dapat dipindah-pindah dan satu tempat ke tempat lain.

c) Radio dapat menyumbang daya imajinasi siswa.

d) Dapat merangsang partisipasi aktif para pendengar.

e) Pelajaran lewat radio lebih bermutu, baik dan segi ilmiyah maupun metodis, karena melalui radio pelajaran dapat disajikan oleh guru-guru yang ahli (qualified)

f) Jangkauan radio luas, dapat mengatasi keterbatasan ruang dan waktu. Radio juga dapat menyajikan pengalaman-pengalaman dunia luar ke kelas.

Adapun kelemahan-kelemahan radio sebagai media pengajaran

antara lain:

a) Sifat komunikasinya hanya satu arah

b) Biasanya siaran disentralisir sehingga guru tidak dapat mengontrolnya.

c) Penjadwalan pelajaran dan siaran sering menimbulkan problem integrasi siaran radio ke dalam kegiatan belajar mengajar.

2) Tape Recorde

Beberapa kelebihan tape recorder sebagai media pelajaran yaitu :

a) Mempunyai fungsi ganda yang efektif sekali untuk merekam dan menghapusnya.

b) Dapat diputar berulang-ulang tanpa mempengaruhi volume.

c) Rekaman dapat dihapus secara otomatis dan tape bisa dipakai lagi. 
d) Tape Recorder dapat digunakan sesuai dengan jadwal yang ada, guru dapat secara langsung mengontrolnya.

e) Dapat digunakan untuk menyajikan kegiatan-kegiatan diluar sekolah (hasil wawancara)

c. Media Proyektor Soil, Yaitu:

1) OHP (Over Head Projector)

Beberapa manfaat/ kelebihan OHP sebagai media pendidikan yaitu:

a) Gambar yang diproyeksikan lebih jelas jika dibandingkan kalau digambarkan di papan, dan tak perlu ruang gelap.

b) Guru dapat mengajar sambil berhadapan dengan siswa.

c) Dapat memproyeksikan benda-benda kecil.

d) Lebih sehat dan papan tulis.

2) Televisi

Sebagai suatu medium, televisi mempunyai beberapa kelebihan :

a) Televisi merupakan medium yang menarik, up to date dan selalu siap diterima oleh anak-anak, karena mereka mengenalnya sebagai bagian dan kehidupan luar sekolah

mereka.

b) Televisi dapat memikat perhatian sepenuhnya dan penonton seperti halnya film, menyajikan informasi visual dan suditif secara simultan.

c) Sifatnya langsung dan nyata.

d) Batas ruang dan waktu dapat diatasi.

e) Hampir semua mata pelajaran dapat di TV kan.

f) Televisi dapat meningkatkan pengetahuan dan kemampuan guru dalam hal mengajar.

Meskipun televisi dapat membenkan manfaat, tetapi banyak pula problem yang perlu diatasi antara lain:

a) Harga televisi relatif mahal

b) Jadwal sering bertubrukan antara lain siaran dan jam pelajaran.

c) Tidak selamanya program televisi cocok dan jelas.

d) Sifat komunikasinya satu arah, menurut Oemar Hamalik, 1996: 32-41) 


\section{B. Prestasi Belajar Belajar}

Yang dimaksud dengan prestasi belajar disini adalah: berasal dari kata prestasi dan belajar. prestatie (Belanda) yang diartikan hasil usaha yang dicapai melalui kemampuan dan ketramplan yang dimilikinya.(Zaenal Arifin 1999:3). Sedang belajar adalah usaha secara sadar secara sengaja merubah tingkah lakusehingga memperoleh pengertian yang barudengan jelas melalui latihan-latihan. Jadi prestasi belajar adalah sebagai tingkat keberhasilan murid dalam mempelajari materi pelajaran ndi sekolah yang dinyatakan dalam bentukskor yang diperoleh dari hasil test materi pelajran tertentu.

Dalam melakukan belajar juga harus ada motivasi baik dari dalam maupun dari luar diri manusia. Motivasi adalah daya penggerak didalam diri anak yang mampu menimbulkan kesenangan atau kegairahan yang bentuknya ada dua yaitu:

a. Motivasi instrinstik adalah bentuk motivasi atau kesediaan karena terdorong oleh rasa ingin tahu.

b. Motivasi ekstrinstik adalah bentuk motivasi atau kesediaan karena dorongan untuk mendapatkan sesuatu. (Afifudin, 1988: 110-111)

Jadi motivasi merupakan suatu yang dapat dilihat dalam menjalankan aktifitas seperti halnya tingkah laku yang menjadi aktif pada saat-saat tertentu untuk mencapai tujuan yang dilakukan atau dihayati.

Motivasi sangat berguna bagi tindakan atau perbuatan seseorang karena mempunyai kegunaan antara lain:

1. Motivasi mendorong manusia untuk berbuat atau bertindak. Motivasi juga berfungsi sebagai penggerak atau sebagai motor yang memberikan energi untuk melakukan tugas.

2. Motivasi dapat menentukan arah perbuatan yakni ke arah perwujudan suatu cita-cita atau tujuan. Motivasi mencegah penyelewengan dan jalan vang harus ditempuh untuk mencapai tujuan tersebut.

3. Monvasi dapat menyeleksi perbuatan kita. Artinya untuk menentukan perbuatan-perbuatan mana yang harus dilakukan serasi guna mencapai tujuan itu dengan meniadakan perbuatan yang tidak bermanfaat bagi tujuan itu. (Ngalim Purwanto, 1990: 70-71)

Dan beberapa motivasi yang telah diuraikan, kita mengetahui bahwa tiap-tiap teori memiliki kelemahan dan kekurangannya masing-masing. Namun jika kita hubungkan dengan manusia sebagai pribadi dam kehidupan sehan-hari, teori-teori motivasi yang telah dikemukakan ternyata memiliki hubungan yang komplementer yang berarti saling melengkapi satu sama lain. 
Beberapa saran pengembangan motivasi dalam dunia pendidikan yang dapat kita lakukan misalnya, kita dapat mengatur dan menyediakan situasi-situasi baik dalam keluarga maupun di lingkungan sekolah yang memungkinkan timbulnya kompetisi yang sehat antar anak didik kita dengan jalan menimbulkan perasaan puas terhadap hasil-hasil prestasi yang telah dicapai. Membiasakan anak didik mendiskusikan suatau pendapat atau cita-cita mereka masing-masing. Tunjukan. kepada mereka dengan contoh kongkrit dalam kehidupan seharihari dalam masyarakat bahwa dapat tercapai tidaknya suatu maksud dan tujuan sangat tergantung pada motivasi apa yang mendorong untuk mencapai maksud dan tujuan itu.

Seorang siswa yang mempunyai motivasi belajar yang tinggi sebagai berikut:

1. Tertarik kepada guru, artinya tidak membenci atau bersikap acuh tak acuh.

2. Tertarik pada mata pelajaran yang diajarkan.

3. Mempunyai antusias yang tinggi dan mengendalikan perhatian terutama pada guru.

4. Ingin selalu bergabung dalam kelompok kelas.

5. Ingin identitas dirinya diakui oleh orang lain.

6. Tindakan, kebiasaan dan moralnya selalu dalam kontrol diri

7. Selalu mengingat pelajaran dan mempelajarinya kembali.

8. Selalu kontrol oleh lingkungannya. (Oemar Hamalik, 1996: 88)

Unsur-unsur yang mempengaruhi motivasi belajar siswa cukup banyak, baik yang berasal dan diri siswa sendiri maupun yang berasal dan luar diri siswa. Monks, Singgih Gunarso, berpendapat seperti yang dikutip Dimyati unsur-unsur tersebut adalah:

1. Cita-cita/ aspirasi pembelajar

2. Kemampuan pembelajar

3. Kondisi pembelajar

4. Kondisi lingkungan belajar

5. Unsur-unsur dinamis belajar

6. Upaya guru dalam membelajarkan pembelajaran (2006 :97-98)

Kita tahu bahwa waktu yang digunakan belajar di sekolah adalah sangat terbatas dan relatif sedikit dibandingkan materi yang dikuasai anak. Oleh sebab itu untuk mengatasi keterbatasan waktu belajar di sekolah, siswa harus belajar di rumah, guru harus dapat merangsang agar siswa mau belajar di rumah. Hal ini dapat dilakukan dengan memberi tugas yang dikerjakan di rumah. Tugas itu dapat berupa perintah membaca, meresume atau mengerjakan soal latihan. Anak yang berminat belajar tentu akan menyediakan waktu untuk tugas-tugas tersebut, bahkan tanpa tugas atau perintah ia akan dengan sadar dan tanggung jawab 
melaksanakan tugas belajar seperti mengulang pelajaran yang telah diberikan, mencoba mempelajari pelajaran yang akan diberikan.

Kesemuanya ini akan terwujud apabila siswa tersebut mempunyai kesediaan secara aktif dan disiplin melaksanakan aktifitas di atas. Kesediaan belajar ini akan terlihat dari kedisiplinan belajar, minat belajar, sikap dalam belajar dan usaha memenuhi sarana belajar. Ini yang dikatakan anak mempunyai motivasi belajar di rumah.

Anak yang tidak mempunyai motivasi belajar di rumah, akan acuh tak acuh dengan waktu yang ada di rumah, juga acuh tak acuh terhadap tugas seperti di atas. Walaupun telah diingatkan disuruh dan dinasehati ia akan menggerutu. Walaupun mau belajar hanya karena terbatas, jadi tidak ada kesediaan diri untuk belajar. Pada umumnya motivasi intrinsik lebih kuat dan lebih baik dari pada motivasi ekstrinsik oleh karena itu bangunkanlah motivasi intrinsik pada anak-anak didik kita. Jangan hendaknya anak mau belajar dan bekerja hanya karena takut dimarahi, dihukum, mendapat angka merah atau takut tidak lulus dalam ujian.

C. Pendidikan Kewarganegaraan

Pendidikan di Indonesia diharapkan dapat mempersiapkan peserta didik menjadi warga negara yang memiliki komitmen kuat dan konsisten untuk mempertahankan Negara Kesatuan Republik Indonesia. Mata pelajaran Pendidikan Kewarganegaraan yang memfokuskan pada pembentukan warga negara yang memahami dan mampu melaksanakan hak-hak dan kewajibannya untuk menjadi warga negara Indonesia yang cerdas, trampil, dan berkarakter yang diamanatkan oleh Pancasila dan UUD 1945. (BSNP, 2005: 37).

Adapun tujuan Pendidikan Kewarganegaraan bertujuan agar peserta didik memiliki kemampuan sebagai berikut:

1. Berpikir secara kritis, rasional dan kreatif dalam menanggapi isu kewarganegaraan.

2. Berpartisipasi secara aktif dan bertanggung jawab dan bertindak secara cerdas dalam kegiatan bermasyarakat, berbangsa dan bernegara serta anti korupsi.

3. Berkembang secara positif dan demokratis untuk membentuk diri berdasarkan karakterkarakter masyarakat Indonesia agar dapat hidup bersama dengan bangsa-bangsa lainnya.

4. Berinteraksi dengan bangsa-bangsa lain dalam peraturan dunia secara langsung atau tidak langsung dengan memanfaatkan teknologi, informasi dan komunikasi. (BSN 2003 : ...)

Dalam UU Sistem Pendidikan Nasional no.20 Tahun 2003 dalam pasal 3 disebutkan bahwa tujuan pendidikan untuk berkembangnya potensi peserta didik agar menjadi manusia yang berimana dan bertakwa kepada Tuhan Yang Maha Esa berakhlak mulia, sehat berilmu, cakap, kreatif, mandiri dan menjadi warga negara yang demokratis dan bertanggung jawab. 
Berdasarkan uraian di atas maka untuk berkembangnya potensi peserta didik harus dimotivasi agar anak belajar, karena salah satu aspek penting dalam mengajar termasuk mengajar PKn ialah membangkitkan motivasi.

D. Pengaruh Media Pendidikan Terhadap Prestasi Belajar

Media pendidikan sebagai alat yang digunakan dalam proses pembelajaran, sedemikian rupa harus merupakan sarana yang digunakan oleh pendidik dalam upaya diperoleh prestasi pembelajaran yang lebih baik. Namun demikian tidak hanya merupakan alat pembelajaran saja, diharapkan media pendidikan ini juga merupakan metode yang digunakan para guru dalam mengungkap sebuah materi pembelajaran dengan konsep kenyataan atau dalam bentuk fisik dimana siswa akan lebih memahami arti dan teori yang telah dipelajari sebelumnya. Karena belum tentu siswa akan begitu saja tahu dan mengerti sebuah kajian teori sebuah mata pelajaran yang telah diberikan oleh gurunya.

Sementara itu dalam menyajikan suatu mata pelajaran tidak lepas pula dengan metode mengajar yang digunakannya dan alat bantu media pendidikan bagi guru dan siswa khususnya merupakan alat atau sarana atau perwujudan dari bentuk abstrak sebuah teori ke bentuk nyata atau benda yang dapat dilihat atau didengar atau dirasakan.

Media pendidikan dapat digunakan dalam proses pembelajaran yang gunakan oleh pendidik dalam upaya mencapai prestasi pembelajaran yang lebih baik dan tepat dalam upaya mengembangkan ilmu pengetahuan dewasa ini. Media pendidikan juga merupakan alat dan metode yang digunakan oleh para guru dalam mengungkap suatu materi pembelajaran dengan konsep teori yang telah dipelajari sebelumnya.

Bagi guru dalam menyajikan suatu mata pelajaran tidak lepas pula dengan metode mengajar yang menggunakan metode atau alat bantunya adalah media pendidikan bagi guru dan siswa khususnya merupakan alat atau sarana untuk mewujudkan bentuk benda yang menuju ke bentuk kenyataan atau yang dapat dilihat melalui indera penglihat atau dapat didengar oleh indera pendengar dan dapat dirasakan.

Media pendidikan sangatlah penting bagi anak didik dalam kegiatan belajar untuk dapat membantu dan mengmgatkan sebuah teori yang diajarinya. Media pendidikan merupakan pelengkap dalam kegiatan suatu organisasi sosial, ekonomi, politik dan budaya. Tanpa media pendidikan yang lengkap tepat dan serasi, maka akan sulit dirasakan tercapainya program organisasi.

Media pendidikan identik dengan pengertian peraga yang berasal dari kata raga" artinya suatu benda yang dapat diraba, didengar dan dapat diamati melalui panca indera. Media pendidikan digunakan dalam rangka hubungan (komunikasi) dalam pembelajaran, antara guru 
dan siswa. Media pendidikan juga merupakan alat bantu belajar mengajar, baik dalam kelas maupun di luar kelas. Media pendidikan mengandung aspek-aspek sebagai alat dan sebagai teknik yang sangat erat pertaliannya dengan metode mengajar.

E. Pengajuan Hipotesis

Hipotesis adalah jawaban sementara, yang masih harus dibuktikan kebenarannya, melalui kegiatan penelitian. Hipotesis digolongkan menjadi Pertama Ho atau hipotesis nihil dalam hal ini dinyatakan. "Tidak ada pengaruh antara penggunaan media dengan prestasi belajar PKn siswa kelas X SMK Perindustrian Yogyakarta tahun 2016”.

\section{METODE}

Dalam penelitian ini menggunakan pendekatan kuantitatif. Pendekatan kuantitatif adalah suatu pendekatan yang mengajukan hipotesis dan hipotesis tersebut diuji dengan teknik statistik tertentu.

\section{A. Tempat dan Waktu Penelitian}

Penelitian ini dilaksanakan di SMK Perindustrian Yogyakarta. Sedang waktu pelaksanaan penelitian ini dilaksanakan lebih kurang tiga (3)bulan mulai bulan Mei sampai dengan bulan Juli 2016.

B. Populasi dan Sampel

Populasi dalam penelitian ini adalah semua siswa kelas $\mathrm{X}$ yang berjumlah 120 siswa, dengan rincian sebagai berikut:

$\begin{array}{ll}\text { Kelas X A } & \text { :30 siswa } \\ \text { Kelas X B1 } & : 30 \text { siswa } \\ \text { Kelas X B2 } & : 25 \text { siswa } \\ \text { Kelas X B3 } & : 40 \text { siswa }\end{array}$

Sedang sampel penelitian ini menggunakan purpose random sampling yang diambil dengan menggunakan undian yaitu pada kelas XB3 di SMK Perindustrian Yogyakarta sebagai 40 siswa.

C. Variabel Penelitian

Variabel terdiri dari 2 (dua) variabel yaitu variabel bebas; media pendidikan, dan variabel terikat adalah prestasi belajar bidang studi PKn siswa kelas X, sebagai berikut:

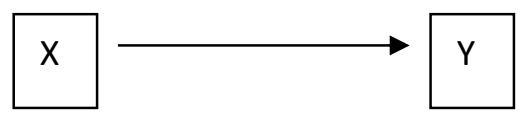

$\mathrm{X} \quad$ : variabel bebas (pengaruh media pendidikan )

$\mathrm{Y} \quad$ : variabel terikat (prestasi belajar siswa kelas X) 
D. Teknik Pengumpulan Data

Teknik pengumpulan data yang digunakan dalam penelitian ini adalah angket atau kuesioner dan dokumentasi. Angket digunakan untuk memperoleh data variabel bebas. Sedangkan variabel terikat dengan dokumentasi yaitu data siswa dan nilai bidang studi PKn.

Penyusunan instrumen penelitian dengan membuat angket atau kuesioner disusun dengan mengacu pada penggunaan media pada proses pembelajaran. Untuk kisi-kisi instrumen sebagai berikut:

\begin{tabular}{|l|l|c|l|}
\hline No. & \multicolumn{1}{|c|}{ Uraian } & Jumlah item & \multicolumn{1}{|c|}{ Keterangan } \\
\hline 1. & Pelaksanaan pembelajaran & 5 & No. $1-5$ \\
\hline 2. & Penggunaan media & 5 & No. $6-10$ \\
\hline 3. & Motivasi belajar & 5 & No.11 -15 \\
\hline 4. & Evaluasi belajar & 5 & No.16-20 \\
\hline
\end{tabular}

Dalam penelitian ini penulis menggunakan angket tertutup dan secara langsung, artinya responden dalam menjawab pertanyaan tinggal memilih jawaban yang sudah ada. Sedangkan skor tiap item angket ditemukan berdasarkan setiap pertanyaan bergantung jumlah pilihan jawabannya.

Adapun untuk memberikan skor terhadap jawaban positif responden sebagai berikut:
a. Jawaban a, mendapat skor 5 (lima)
b. Jawaban b, mendapat skor 4 (empat)
c. Jawaban c, mendapat skor 3 (tiga)
d. Jawaban d, mendapat skor 2 (dua)
e. Jawaban e, mendapat skor 1 (satu)

Sedangkan jika jawaban negatif :
a. Jawaban a, mendapat skor 1 (skor)
b. Jawaban b, mendapat skor 2 (dua)
c. Jawaban c, mendapat skor 3 (tiga)
d. Jawaban d, mendapat skor 4 (empat)
e. Jawaban e, mendapat skor 5 (lima)

\section{E. Teknik Analisis Data}

Untuk menganalisis data digunakan uji statistik. Namun demikian Suharsimi Arikunto menjelaskan lebih lanjut. Analisis yang digunakan dalam perhitungan deskriptif kuantitatif yaitu data yang diperoleh dijumlahkan, diklasifikasikan, sehingga merupakan susunan urut data dan selanjutnya dibuat tabel. Tabel tersebut kemudian diproses lebih lanjut menjadi perhitungan pengambilan kesimpulan dan visualisasi data. 


\section{Analisis deskripsi kuantitatif dengan persentase.}

Dipergunakan teknik deskriptif kuatitatif dengan prosentase yaitu dari data yang terkumpul kemudian diklasifikasikan menjadi dua kelompok yaitu data kualitatif dan data kuantitatif. Untuk data yang bersifat kualitatif digambarkan dalam kalimat misalnya, kelompok baik sekali. Sedangkan data yang bersifat kuantitatif yang benwujud angka-angka hasil perhitungan diperoleh dengan cara dijumlahkan, dibandingkan yang kemudian dimasukkan ke dalam bentuk-bentuk persentase sebagai berikut:

\section{Jumlah nilai responden}

\section{Keterangan:}

Responden $\mathrm{x}$ jumlah soal $\mathrm{x}$ skor maksimal

$$
\text { x } 100 \%
$$

1. Jumlah nilai responden adalah jumlah skor angket

2. Responden adalah jumlah sampel yang diteliti

3. Jumlah soal adalah jumlah item angket yang akan dianalisa.

4. Skor maksimal adalah skor jawaban tertinggi angket.

Adapun rumus di atas dapat digunakan unluk mengolah data yang bersifat kualitatif yaitu:

$90 \%-100 \%=$ baik $; 70 \%-79 \%=$ cukup

$80 \%-89 \%=$ baik ; $60 \%$ - bawah $=$ kurang baik

Sumber: (Suharsimi Arikunto, 1987: 24)

2. Teknik analisis untuk mencari pengaruh

Untuk mencari adakah hubungan antara variable $\mathrm{X}$ dan $\mathrm{Y}$ dipergurangan teknik analisis product moment yang mendasarkan pada selisih skor kasarnya, adapun formulanya seperti berikut.

$$
r_{x y}=\frac{\left.N \sum X^{2}+\sum Y^{2}-\sum(X-Y)^{2}\right\rfloor-2\left(\sum X\right)\left(\sum Y\right)}{2 \sqrt{\left[N \sum X^{2}-\left(\sum X\right)^{2}\right.}\left[N \sum Y^{2}-\left(\sum Y\right)^{2}\right]}
$$

$\mathrm{N}=$ number of cases

$\sum X^{2}=$ Jumlah kuadrat skor $\mathrm{X}$

$\sum Y^{2}=$ Jumlah kuadrat skor $\mathrm{Y}$

$(\mathrm{X}-\mathrm{Y})=$ selisih antara skor variable $\mathrm{X}$ dengan skor variable $\mathrm{Y}$

$(\mathrm{X}-\mathrm{Y})^{2}=$ kuadrat selisih skor variable $\mathrm{X}$ dan skor variable $\mathrm{Y}$

$(\Sigma X)^{2}=$ jumlah skor variable $\mathrm{X}$ kemudian dikuadratkan

$(\Sigma \mathrm{Y})^{2}=$ jumlah skor variable $\mathrm{Y}$, kemudian dikuadratkan

2 = bilangan konstans, menurut (Anas Sudijono, 1987 : 204) 


\section{PEMBAHASAN}

A. Deskripsi hasil penelitian dan pembahasan

Hasil penyebaran angket ini kemudian diskor dan perolehan nilai angket selengkapnya ada pada lampiran II, dan hasil angket tersebut dapat disajikan pada data-data berikut: Dengan hasil pemberian skor angket dari tabel pengumpulan data dan diuraikan berdasar tabel daftar kisi-kisi angket dapat diperoleh perhitungan persentase sebagai berikut:

Jumlah nilai responden

Keterangan : x $100 \%$

responden $\mathrm{x}$ jumlah item soal $\mathrm{x}$ skor maksimal

1. Jumlah nilai responden adalah jumlah skor angket.

2. Responden adalah jumlah sampel yang diteliti.

3. Jumlah soal adalah jumlah item angket yang akan dianalisis.

4. Skor maksimal adalah skor jawaban tertinggi angket.

1. Analisis deskriptif kuantitatif dengan persentase

Adapun analisis data perhitungan yang diambil berdasarkan indikator kisi-kisi angket dapat dijelaskan sebagai berikut:

1. Indikator 1, tentang minat siswa dalam mengikuti pelajaran yang penyajiannya menggunakan media pendidikan, nomor: 1, 2, 3, 4, 5 dianalisis sebagai berikut:

$$
\begin{gathered}
761 \\
1000
\end{gathered}
$$

2. Indikator 2 , tentang sejauh mana perhatian siswa terhadap penggunaan media pembelajaran nomor: $6,7,8,9,10$ dianalisis sebagai berikut :

$$
\begin{array}{r}
781 \\
=-----\times 100 \%=78,1 \% \\
1000
\end{array}
$$

3. Indikator 3, tentang motivasi belajar siswa dalam proses pembelajaran yang disampaikan oleh guru, nomor: 11, 12, 13, 14, 15 dianalisis sebagai berikut :

$$
\text { =------ } \times 100 \%=84,9 \%
$$

4. Indokator 4, tentang perasaan siswa terhadap evaluasi proses pembelajaran, nomor: 16, 17, 18, 19, 20 dianalisis sebagai berikut :

$$
\begin{gathered}
\text { =------ x } 100 \%=75,3 \% \\
1000
\end{gathered}
$$


Berdasarkan hasil persentase masing-masing indikator di atas maka dapat diketahui jumlah skor analisis persentase keseluruhan adalah:

3144

$$
\text { = ------ x } 100 \%=78,6 \%
$$

Berdasar jumlah persentase keseluruhan $=78,6 \%$

Kemudian dikonsultasikan dengan tabel persentase sebagai berikut :

$$
\begin{array}{ll}
90 \%-100 \% & =\text { Baik sekali } \\
80 \%-89 \% & =\text { Baik } \\
70 \%-79 \% & =\text { Cukup } \\
60 \%-\text { ke bawah } & =\text { Kurang baik }
\end{array}
$$

Adapun jumlah hasil perhitungan diperoleh antara 70\% sampai dengan 79\% maka dapat ikatakan bahwa peranan media pendidikan dalam upaya meningkatkan prestasi belajar cukup di SMK Perindustrian Yogyakarta tahun pelajaran 2015/2016.

2. Analisis untuk mencari pengaruh

Untuk mencari korelasi antara variable $\mathrm{X}$ dan variable $\mathrm{Y}$, dipersiapkan table 1 berikut.

Tabel 1 Distribusi skor hasil sebaran angket indicator 2 dan indikator 3.

\begin{tabular}{|l|l|l|l|l|l|}
\hline No. & \multicolumn{1}{|c|}{$\mathrm{X}$} & \multicolumn{1}{|c|}{$(\mathrm{X}-\mathrm{Y})^{2}$} & \multicolumn{1}{c|}{$\mathrm{X}^{2}$} & $\mathrm{Y}^{2}$ \\
\hline 1 & 23 & 22 & 1 & 529 & 484 \\
\hline 2 & 18 & 18 & 0 & 324 & 324 \\
\hline 3 & 23 & 22 & 1 & 529 & 484 \\
\hline 4 & 21 & 21 & 0 & 441 & 441 \\
\hline 5 & 22 & 23 & 1 & 484 & 529 \\
\hline 6 & 18 & 23 & 25 & 324 & 529 \\
\hline 7 & 20 & 21 & 1 & 400 & 441 \\
\hline 8 & 20 & 20 & 0 & 400 & 400 \\
\hline 9 & 17 & 19 & 4 & 289 & 361 \\
\hline 10 & 20 & 19 & 1 & 400 & 361 \\
\hline 11 & 18 & 23 & 25 & 324 & 529 \\
\hline 12 & 18 & 23 & 25 & 324 & 529 \\
\hline 13 & 21 & 22 & 1 & 441 & 484 \\
\hline 14 & 18 & 21 & 9 & 324 & 441 \\
\hline 15 & 22 & 22 & 0 & 484 & 484 \\
\hline 16 & 20 & 18 & 4 & 400 & 414 \\
\hline 17 & 20 & 22 & 4 & 400 & 484 \\
\hline 18 & 21 & 23 & 4 & 441 & 529 \\
\hline 19 & 19 & 21 & 4 & 361 & 441 \\
\hline 20 & 20 & 20 & 0 & 400 & 400 \\
\hline 21 & 20 & 21 & 1 & 400 & 441 \\
\hline 22 & 20 & 24 & 16 & 400 & 576 \\
\hline 23 & 22 & 22 & 0 & 484 & 484 \\
\hline 24 & 21 & 20 & 1 & 441 & 400 \\
\hline & & & & & \\
\hline
\end{tabular}




\begin{tabular}{|l|l|l|l|l|l|}
\hline 25 & 20 & 19 & 1 & 400 & 361 \\
\hline 26 & 21 & 20 & 1 & 441 & 400 \\
\hline 27 & 22 & 18 & 9 & 484 & 324 \\
\hline 28 & 20 & 22 & 4 & 400 & 484 \\
\hline 29 & 21 & 24 & 9 & 441 & 576 \\
\hline 30 & 18 & 24 & 36 & 324 & 576 \\
\hline 31 & 18 & 17 & 1 & 324 & 289 \\
\hline 32 & 20 & 22 & 4 & 400 & 484 \\
\hline 33 & 17 & 23 & 25 & 289 & 529 \\
\hline 34 & 16 & 20 & 16 & 256 & 400 \\
\hline 35 & 18 & 20 & 4 & 324 & 400 \\
\hline 36 & 16 & 18 & 4 & 256 & 324 \\
\hline 37 & 19 & 25 & 36 & 361 & 625 \\
\hline 38 & 18 & 23 & 25 & 324 & 529 \\
\hline 39 & 18 & 22 & 16 & 324 & 484 \\
\hline 40 & 17 & 22 & 25 & 289 & 484 \\
\hline & $\Sigma \mathrm{X}=$ & $\Sigma \mathrm{Y}=$ & $\Sigma(\mathrm{X}-$ & $\Sigma \mathrm{X}^{2}=15381$ & $\Sigma \mathrm{Y}^{2}=18259$ \\
& 781 & 849 & $\mathrm{Y})^{2}=319$ & & \\
\hline
\end{tabular}

Mencari harga koefisien korelasi product moment $\left(\mathrm{r}_{\mathrm{xy}}\right)$

Dengan memasukkan harga-harga

$\Sigma \mathrm{X}=781 \Sigma \mathrm{Y}=849 \Sigma(\mathrm{X}-\mathrm{Y})^{2}=319 \Sigma \mathrm{X}^{2}=15381$ dan $\Sigma \mathrm{X}^{2}=18259$ kedalam rumus korelasi product moment (halaman 32),

$$
\begin{aligned}
r_{x y} & =\frac{40(15381+18259-319)-2(781)(849)}{2 \sqrt{\left.(40 \times 15381)-(781)^{2}\right)(40 \times 18259)-(849)^{2}}} \\
& =\frac{1332840-1326138}{2 \sqrt{5279 \times 9559}} \\
& =\frac{6702}{2 x 7103,658} \\
& =\frac{6702}{14207,3} \\
& =0,4717
\end{aligned}
$$

B. Pengujian Hipotesis

Pengujian hipotesis dilakukan dengan mengkonsultasikan harga koefisien korelasi hasil perhitungan $\left(\mathrm{r}_{\mathrm{xy}}\right)$ dengan harga $\mathrm{r}$ table, pada $\mathrm{db}=\mathrm{N}-\mathrm{nr}=40-2=38$, dan signifikansi $5 \%$. Pada table harga $\mathrm{r}$, tidak terdapat $\mathrm{db}=38$ sehingga diambil $\mathrm{db}=40$. Harga $\mathrm{r}$ table pada $\mathrm{db}=$ 40, taraf sigifikansi $5 \%=0,304$ sedangkan taraf signifikansi $1 \%=0,393$. Sehingga harga $\mathrm{r}$ hitung lebih besar dari pada harga $r$ table, baik pada tingkat keberartian $5 \%$ maupun $1 \%$ atau $0,4717>0,393$ atau $0,4717>0,304$. Dengan demikian maka hipotesis alternatih (Ha) yang 
berbunyi "Tidak pengaruh penggunaan media pendidikan dengan prestasi belajar siswa kelas X SMK Perindustrian Yogyakarta tahun 2016 dapat diterima.

\section{SIMPULAN DAN SARAN}

A. Simpulan

Dari hasil perhitungan penelitian yang telah dilakukan penulis dan berdasarkan kajian teoritis mengenai pengaruh media pendidikan dalam upaya meningkatkan motivasi belajar siswa SMK Perindustrian Yogyakarta tahun pelajaran 2015/ 2016 maka dari hasil penyebaran angket dapat disimpulkan sebagai berikut:

1. Indikator 1, tentang minat siswa dalam mengikuti pelajaran PKn yang penyajiannya mengguna media pendidikan, nomor: 1, 2, 3, 4, 5 diperoleh persentase $=76,1 \%$ dengan kategori cukup. Media mampu merubah minat belajar.

2. Indikator 2, tentang sejauh mana pengaruh media pendidikan oleh guru dalam pembelajaran PKn nomor: 6, 7, 8, 9, 10 diperoleh persentase $=78,1 \%$ dengan kategori cukup.

3. Indikator 3, meningkatkan prestasi siswa dalam mengikuti proses pembelajaran yang disampaikan oleh guru, nomor: $11,12,13,14,15$ diperoleh persentase $=84,9 \%$ dengan kategori baik.

4. Indikator 4, tentang kesan siswa terhadap evaluasi belajar yang dilaksanakan oleh guru nomor: 16, 17, 18, 19, 20 diperoleh persentase $=75,3 \%$ dengan kategori cukup.

Jumlah skor seluruh angket adalah 3144 kemudian diadakan perhitungan diperoleh nilai $=$ 78,6 \% kemudian dikonsultasikan dengan tabel persentase antara 70\% sampai dengan 79\% dengan kategori cukup, maka dapat dikatakan bahwa peranan media pendidikan dalam upaya meningkatkan motivasi belajar siswa SMK Perindustrian Yogyakarta tahun pelajaran 2015/2016 adalah cukup.

Dari perhitungan. harga koefisien korelasi $\mathrm{r}$ hitung $=0,4717$, maka terbukti secara meyakinkan bahwa, penggunaan media pendidikan tidak mempunyai pengaruh dengan prestasi belajar siswa kelas X SMK Perindustrian Yogyakarta, tahun 2016

B. Saran

Media pendidikan yang semakin maju ini diharapkan dapat memberikan kemudahan yang lebih pada ilmu penegtahuan yang akan diungkap. Demikian pula dengan kemudahankemudahan media pendidikan pada jaman modern ini diharapkan dapat meningkatkan prestasi belajar. 
Saran-saran yang mungkin dapat dijadikan himbauan pada sesama guru dan yang seprofesi adalah bahwa guru sebagai ujung tombak diharapkan dengan berbagai cara, alat, sarana dan media sedemikian rupa dapat terus meningkatkan kualitas dan pemberdayaan keprofesionalannya melalui berbagai media pendidikan yang sekarang telah banyak digunakan. Peranan guru dengan media telah tercukupi belum menjamin bahwa proses pendidikan akan berjalan dengan lancar namun juga tak kalah pentingnya adalah memberikan gairah dan motivasi atau minta belajar kepada para siswanya sehingga pemberdayaan media pendidikan tersebut dapat seoptimal mungkin digunakan karena, dapat meningkatkan prestasi belajar siswa.

\section{DAFTAR PUSTAKA}

Departemen Pendidikan dan Kebudayaan, (1995). Kamus Besar Bahasa Indonesia, Edisi II, Jakarta: Balai Pustaka.

Kartini Kartono, (1990). Psikologi Anak, Jakarta: Mandar Maju.

Kuntjaraningrat, (1966). Metodologi Pendidikan Masyarakat, Jakarta: Gramedia.

Masri Singarimbun, (1986). Pedoman Praktis Membuat Usulan Penelitian, Ghalia Indonesia.

Nana Sudjana, (1991). Tuntunan Penyusunan Karya Ilmiah, Bandung: Sinar Baru.

Oemar Malik, (1996). Media Pendidikan, Bandung: Tarsito.

Rachmad Jatun, (1989). Dasar Pendidikan, Surakarta.

Suharsimi Arikunto, (1990). Prosedur Penelitian Suatu Pendekatan Praktek, Jakarta: Bina Aksara.

, (1993). Dasar-Dasar Evaluasi Pendidikan, Jakarta: Bumi Aksara.

Sutrisno Hadi, (1980). Metodologi Riset Jilid III, Jogjakarta: Fakultas Psikologi UGM.

---------, (1981). Statistik II, Jogjakarta: Fakultas Psikologi UGM.

Soegardo Purbocaroko, (1980). Ensiklopedi Pendidikan, Jakarta: Karya Aksara.

Totok Santoso, (1988). Peningkatan Mutu Pendidikan Sebagai Upaya Pengembangan Sumber Daya Manusia.

Winarno Surachmat, (1975). Dasar-Dasar Teknik Riset dan Pengantar Metodologi, Bandung: Tarsito.

WJS Purwodarminto, (1990). Kamus Umum Inggris Indonesia, Bandung: Hasta. 